University of Pennsylvania Carey Law School

Penn Law: Legal Scholarship Repository

Faculty Scholarship at Penn Law

$12-21-2012$

\title{
Antitrust and the 'Filed Rate' Doctrine: Deregulation and State Action
}

Herbert J. Hovenkamp

University of Pennsylvania Carey Law School

Follow this and additional works at: https://scholarship.law.upenn.edu/faculty_scholarship

Part of the Administrative Law Commons, Antitrust and Trade Regulation Commons, Communications Law Commons, Courts Commons, and the Industrial Organization Commons

\section{Repository Citation}

Hovenkamp, Herbert J., "Antitrust and the 'Filed Rate' Doctrine: Deregulation and State Action" (2012). Faculty Scholarship at Penn Law. 1851.

https://scholarship.law.upenn.edu/faculty_scholarship/1851

This Article is brought to you for free and open access by Penn Law: Legal Scholarship Repository. It has been accepted for inclusion in Faculty Scholarship at Penn Law by an authorized administrator of Penn Law: Legal Scholarship Repository. For more information, please contact PennlawIR@law.upenn.edu. 


\title{
Antitrust and the "Filed Rate" Doctrine:
}

\section{Deregulation and State Action}

\section{Herbert Hovenkamp}

\author{
Introduction; Keogh ${ }^{1}$ and Square $D^{2}$
}

Speaking through Justice Brandeis, the Supreme Court held in Keogh that although the Interstate Commerce Act did not exempt railroads from antitrust liability, a private plaintiff may not recover treble damages based on an allegedly monopolistic tariff rate filed with the ICC. ${ }^{3}$ Keogh very likely grew out of Justice Brandeis's own zeal for regulation and his concern for the protection of small business-in this case, mainly shippers whom he felt were protected from discrimination by filed rates. ${ }^{4}$ The Keogh doctrine served to absolutize regulated rates by making them nearly immune from collateral attack. Under various degrees of deregulation, the doctrine makes little sense.

Justice Brandeis gave four reasons for this rule, each of which was later criticized by Judge Friendly (although he ultimately followed Keogh) in the Square D case. First, Justice Brandeis doubted the need for an antitrust remedy, for Interstate Commerce Act $\S 8^{5}$ gave shippers injured by illegal filed rates their actual damages plus attorney's

* Ben V. \& Dorothy Willie Professor of Law, University of Iowa.

${ }^{1}$ Keogh v. Chi. \& N.W. Ry. Co., 260 U.S. 156 (1922). The doctrine applies not only to the antitrust laws, but to non-antitrust challenges as well. See AT\&T Co. v. Cent. Office Tel Co., Inc., 524 U.S. 214 (1998) (state law tortious interference and contract claims brought by reseller of defendant's digital telephone services barred by filed rate doctrine). For the various complexities that can arise when either the agency or the antitrust law is state rather than federal, see 14 HERBERT HOVENKAMP, ANTITRUST LAw II2411i (3d ed. 2012). Some cases speak of the "filed tariff" rather than filed rate doctrine.

See also Entergy La., Inc. v. La. Pub. Serv. Comm'n, 539 U.S. 39 (2003) (filed rate doctrine, which is federal, requires that state regulatory agencies give federal filed rates binding effect).

${ }^{2}$ Square D Co. v. Niagara Frontier Tariff Bureau, Inc., 760 F.2d 1347 (2d Cir. 1985), aff'd, 476 U.S. 409 (1986).

${ }^{3}$ The Interstate Commerce Commission (ICC) has been abolished and some of its activities have been taken over by the Surface Transportation Board. See I[251i. Although many of the cases discussing the filed rate doctrine concerned ICC rates, the doctrine applies to all state and federal regulatory agencies that require the filing of tariffs containing rates.

${ }^{4}$ See StePhen G. Breyer, Brandeis as Legal SEER, 42 BrandeIS L.J. 711 (2004); THOMAS K. McCraw, Prophets of Regulation: Charles Francis Adams, Louis D. Brandeis, James M. LANDiS, Alfred E. KAHN (1984). See also Paul Brickner, Different Styles and Similar Values: The Reformer Roles of Charles Evens Hughes and Louis Dembitz Brandeis in Gas, Electric, and Insurance Regulation, 33 Ind. L. Rev. 893 (2000); Clyde Spillenger, Elusive Advocate: Reconsidering Brandeis as People's Lawyer, 105 Yale L.J. 1445 (1996); Henry W. Bikle, Mr. Justice Brandeis and the Regulation of Railroads, 45 Harv. L. Rev. 4 (1931).

${ }^{5}$ Later at 49 U.S.C. $\$ 11705(b)$. 
fees. ${ }^{6}$ However, Judge Friendly pointed out that antitrust damages are often available to those with remedies under other bodies of federal law. ${ }^{7}$ Moreover, no remedy would be available from the ICC for an approved rate that had in fact been the product of an earlier conspiracy. And increasingly under deregulation, competition has determined reasonableness.

Second, Justice Brandeis emphasized that the filed rate was legal for all purposes and not to be "varied or enlarged by either contract or tort of the carrier." 9 Granting an antitrust damage remedy to some shippers would result in an arbitrarily discriminatory rate structure inconsistent with the purpose of the Interstate Commerce Act to prevent rate discrimination among shippers. Even if every shipper brought an action, the net rates would be discriminatory "unless the highly improbable happened, and the several juries and courts gave to each the same measure of relief." ${ }^{10}$ But Judge Friendly pointed out that modern class actions increase the likelihood that all shippers affected by a monopoly rate can be joined and receive uniform relief and that the Brandeis argument proves too much. In all cases, one who recovers treble damages from a supplier receives a lower net price than those who do not. This puts the successful plaintiff in a favored position over the one who was equally injured but who failed to litigate or did so unsuccessfully. ${ }^{11}$

Third, Justice Brandeis noted that antitrust damages depend on proof that the rate paid exceeded the hypothetical rate that would have prevailed in the absence of the illegal conduct and that this hypothetical rate would have been approved by the ICC. What the ICC would have approved is a question better determined, at least initially, by the Commission rather than by the courts. ${ }^{12}$ But antitrust damages, far from forcing any particular rate on the ICC, merely reflect an estimate of what the price would otherwise have been-neither more nor less accurately than in antitrust cases generally. ${ }^{13}$ Nor are damages necessarily more intrusive on agency processes than the antitrust injunctions available to private parties. ${ }^{14}$

Finally, Justice Brandeis believed that a shipper would not really be injured by an illegal rate that applied equally to its competitors, for all of them would then simply pass on the overcharge to their customers. The loss they actually absorbed would be purely

${ }^{6} \mathrm{Keogh}$, supra, 260 U.S. at 162-163.

${ }^{7}$ Square D, supra, 760 F.2d at 1354.

${ }^{8}$ Id. at $1354-1355$.

${ }^{9}$ Keogh, supra, 260 U.S. at 163.

${ }^{10}$ Ibid.

${ }^{11}$ Square D, supra, 760 F.2d at 1352.

${ }^{12}$ Keogh, supra, 260 U.S. at 163-164.

${ }^{13}$ Square D, supra, 760 F.2d at 1353.

${ }^{14}$ Georgia v. Pa. R.R. Co., 324 U.S. 439 (1945). Of course, no antitrust remedy is available against conduct that the agency is empowered to exempt from the antitrust laws. For some time the Reed-Bullwinkle Act created an absolute immunity for joint ratemaking approved by the ICC. 49 U.S.C. §10706B. But the Motor Carrier Reform Act of 1980 eliminated the immunity. Section 14(a), Pub. L. 96-296, 94 Stat. 804 (July 1, 1980); codified at various sections of 49 U.S.C. 
speculative. ${ }^{15}$ But subsequent antitrust rulings have allowed those who pay an illegal overcharge to recover it (trebled) whether or not they passed it on. ${ }^{16}$ In any event, even if shippers in competition with one another are not injured significantly, the larger injury would accrue to consumers who would ultimately pay more for goods or services delivered by common carriers, or produced with energy supplied by price-regulated utilities.

The Supreme Court's Square $D$ decision conceded that Keogh may have been "unwise as a matter of policy," Congress had had ample opportunity to overturn it but had not done so. ${ }^{18}$ Since then

\footnotetext{
${ }^{15}$ Keogh, supra, 260 U.S. at 164-165.

${ }^{16}$ Hanover Shoe, Inc. v. United Shoe Mach. Corp., 392 U.S. 481 (1968). See II346.

${ }^{17}$ Square D, supra, 476 U.S. at 420.

${ }^{18} \mathrm{Id}$. Applications of Keogh to preclude antitrust damage actions include Simon v. Keyspan Corp., 694 F.3d 196 (2d Cir. 2012) (filed rate doctrine precluded action against electric rates filed with FERC); AT\&T Corp. v. JMC Telecom., LLC, 470 F.3d 525 (3d Cir. 2006), cert. denied, 551 U.S. 1103 (2007) (Keogh barred claim by communications purchaser-reseller that defendant provided substandard service, following AT\&T Corp. v. Central Off. Tel., Inc., 524 U.S. 214, 233 (1998); Arsberry v. State of Illinois, 244 F.3d 558 (7th Cir.), cert. denied, 534 U.S. 1062 (2001) (discussing filed rate doctrine in antitrust challenge by prison inmates to exclusive agreement between state prison and single long distance carrier, resulting in compensation to prison and high fees to prisoners making telephone calls; Town of Norwood v. New England Power Co., 202 F.3d 408 (1st Cir.), cert. denied, 531 U.S. 818 (2000) (Keogh precludes claim of small utility wishing to purchase wholesale power from defendant and claiming a price squeeze); Lifschultz Fast Freight, Inc. v. Consol. Freightways Corp., 805 F. Supp. 1277 (D.S.C. 1992), aff'd, 998 F.2d 1009 (4th Cir.), cert. denied, 510 U.S. 993 (1993) (Keogh precludes private suit claiming that firms regulated by ICC rigged bids by submitting false data to the agency); Berning $v$. Gooding, 643 F. Supp. 26, 29 (D. Or. 1985), aff'd, 820 F.2d 1550 (9th Cir. 1987) (same; agricultural products whose prices were regulated by Secretary of Agriculture under Agricultural Marketing Agreement Act); Wheat Rail Freight Rate Antitrust Litig., 759 F.2d 1305 (7th Cir. 1985), cert. denied, 476 U.S. 1158 (1986) (railroads immune from antitrust claims of alleged price fixing in rates of wheat transport, notwithstanding that they failed to follow all procedures for filing an agreed upon rate by not giving notice to all prescribed persons or requesting a hearing); Minsky v. Auto Drivaway, 757 F.2d 718 (7th Cir.), cert. denied, 469 U.S. 1019 (1984) (filed rate doctrine applied to automobile driveaway services, whose rates were filed with ICC); W. States Wholesale Natural Gas Antitrust Litig., 368 F. Supp. 2d 1110 (D. Nev. 2005), rev'd and remanded, 243 Fed.Appx. 328, 2007 WL 2806331, 2007-2 Trade Cas. \$775,879 (9th Cir. Sept. 24, 2007, unpub.) (lawsuit alleging that natural gas companies conspired to falsely report gas prices, engaged in fraudulent trades designed to create illusion of market that was more active than it was in fact, and false reporting of transactions was barred by Keogh where rates were filed and FERC had plenary jurisdiction over all issues relating to such rates); Texas Commercial Energy v. TXU Energy, Inc., 2004 WL 1777597, 2004-2 Trade Cas. I74,497 (S.D. Tex. June 24, 2004), aff'd, 413 F.3d 503 (5th Cir. 2005), cert. denied, 546 U.S. 1091 (2006) (electricity reseller's federal and state antitrust challenges to high rates in the Balancing Energy Service market barred by filed rate doctrine, even though rates were set by state regulatory agency); Utilimax.com, Inc. v. PPL Energy Plus, LLC, 273 F. Supp. 2d 573 (E.D. Pa. 2003),
} 
the Supreme Court and lower courts have persisted in applying the doctrine and have even broadened its scope.

The implications of Keogh and Square $D$ are that overcharge actions by consumers based on claims that a "filed" rate ${ }^{19}$ constitutes an antitrust violation will be dismissed. The rate must merely be filed and technically approved by the agency. It need not have

aff'd, 378 F.3d 303 (3d Cir. 2004) (filed rate doctrine barred claim by purchaser-reseller of electric power); Cal. Wholesale Elec. Antitrust Litig., 244 F. Supp. 2 d 1072 (S.D. Cal. 2003), aff'd, 384 F.3d 756 (9th Cir. 2004), cert. denied, 545 U.S. 1149 (2005) (filed rate doctrine barred state antitrust law claim against a rate filed with a federal agency (FERC)); Green v. Peoples Energy Corp., 2003 WL 1712566, 2003-1 Trade Cas. I[73,999 (N.D. Ill. Mar. 28, 2003) (filed rate doctrine precluded tying challenge to tariff requirement that made company-installed gas meters mandatory and required customers to pay a fee for them); Miranda v. Michigan, 141 F. Supp. $2 \mathrm{~d} 747$ (E.D. Mich. 2001) (filed rate doctrine precluded antitrust claims by recipients of long distance collect calls from prisoners, complaining about high collect call rates); Norcen Energy Res., Ltd. v. Pac. Gas \& Electric Co., 1994 WL 519461, 1994-2 Trade Cas. II70,851 (N.D. Cal. Sept. 19, 1994, unreported) (rejecting gas purchaser's argument that Keogh does not apply to a price squeeze created by high federally regulated rates and low state regulated rates). See also Cnty. of Stanislaus v. Pac. Gas \& Elec. Co., 1995 WL 819150, 1996-1 Trade Cas. II71,305 (E.D. Cal. Dec. 18, 1995), aff'd, 114 F.3d 858 (9th Cir. 1997), cert. denied, 522 U.S. 1076 (1998) (Keogh barred consumer challenge to rates filed with Canadian regulatory agency even though agency was not within United States jurisdiction; however, a United States agency had actually participated and reviewed the rate in question).

See also 3B Phillip E. Areeda \& Herbert Hovenkamp, Antitrust Law $1787 \mathrm{c} 1$ (3d ed. 2007), discussing Goldwasser v. Ameritech Corp., 222 F.3d 390, 402 (7th Cir. 2000), which held that the filed rate doctrine precluded a consumer challenge to a telephone interconnection dispute. Accord Stein v. Pac. Bell Tel. Co., 173 F. Supp. 2 d 975 (N.D. Cal. 2001), aff'd in part, vacated in part, 172 Fed.Appx. 192, 2006 WL 751812, 2006-1 Trade Cas. 975,287 (9th Cir. Mar. 22, 2006), on remand, 2007 WL 831750 (N.D. Cal. Mar. 19, 2007) (filed rate doctrine precluded claim brought by customers that they paid too much to defendant). Cf. E. \& J. Gallo Winery v. Encana Energy Servs., Inc., 2005 WL 2230530, 2005-2 Trade Cas. I[74,955 (E.D. Cal. Sept. 14, 2005) (whether filed rate doctrine barred plaintiffs' claims presented a fact question when it was not clear that the retail rates paid by the plaintiff were determined in accordance with filed wholesale rates; the retail rates, which themselves were not filed, could have been set without any reference to the wholesale rates; court assumed that if the retail rate was "pegged," or formulated from the wholesale rate, then filing of the wholesale rate precluded a challenge to the retail rate).

${ }^{19}$ The "filed rate" doctrine itself is not an antitrust doctrine; it derives from the more general public utility rule that once a rate is filed with a regulatory agency, the company is forbidden to charge a different rate. See, e.g., Maislin Indus., Inc. v. Primary Steel, Inc., 497 U.S. 116, 126 (1990); Ark. La. Gas Co. v. Hall, 453 U.S. 571, 577 (1981); Brizendine v. Cotter \& Co., 4 F.3d 457, 460 (7th Cir. 1993), vacated on other grounds, 511 U.S. 1103 (1994). Historically, the rule was so strict that it entitled a railroad to sue for the shortfall when it undercharged a shipper owing to the railroad's own mistake. Louisville \& Nashville R.R. Co. v. Maxwell, 237 U.S. 94, 96 (1915) ("ignorance or misquotation of rates is not an excuse for paying or charging either less or more than the rate filed."). 
been actively reviewed for accuracy or public interest considerations-indeed, it need not have been reviewed at all in any meaningful sense. ${ }^{20}$ The doctrine operates as a rule against collateral attack: once filed, a rate may not be collaterally attacked in the courts. However, an objector may be able to ask the regulatory agency to review a rate within its jurisdiction, considering the objection. ${ }^{21}$ Of course, that proceeding would not be in antitrust and would not provide treble damages and attorney's fees as an inducement.

But the rate must in fact be "filed" before the immunity takes effect. ${ }^{22}$ For example, some regulatory regimes regulate some but not all of a firm's prices. An electric utility may sell its electricity at regulated rates but sell installation services or appliances in competition with private firms at rates that are not regulated at all and are not subject to a filed tariff. In that case, the Keogh immunity applies to the former but not to the latter. Or, under modern electric utility deregulation, "retail" electric power rates to end users are regulated by the agency, while some "wholesale" rates for sales between utilities are not subject to regulatory tariffs. Completely unregulated wholesale rates would not enjoy a Keogh immunity. ${ }^{23}$

Further, the antitrust action must be against the rate itself, not against an underlying conspiracy that may have produced the rate. Thus in Georgia ${ }^{24}$ the Supreme Court permitted an action challenging a conspiracy among railroads to charge a high rate, but not their subsequent filing; nor did the state of Georgia seek damages for any

${ }^{20}$ See Miss. Power \& Light Co. v. Mississippi, 487 U.S. 354, 374 (1988) (non-antitrust case; filed rate doctrine does not turn on "whether a particular matter was actually determined in the FERC proceedings"); Square D Co. v. Niagara Frontier Tariff Bureau, Inc., 760 F.2d 1347 (2d Cir. 1985), aff'd, 476 U.S. 409, 417 n.19 (1986).

${ }^{21}$ Further, a court may be able to review the commission's decision under the ordinary rules for review of administrative decisions. Miss. Power, supra, 487 U.S. at 375.

${ }^{22}$ However, see Ib for application under deregulation, where rates may not be "filed" in any meaningful sense at all.

${ }^{23}$ Fla. Mun. Power Agency v. Fla. Power \& Light Co., 64 F.3d 614 (11th Cir. 1995) (Keogh would not apply if the particular service that the plaintiff wished to purchase from the defendant (wholesale power) was not covered by the tariff fixing the rates). See also Stand Energy Corp.v. Columbia Gas Transmission Corp., 373 F. Supp. 2d 631 (S.D.W.V. 2005), partial reconsideration, 521 F. Supp. 2d 537 (S.D. W.Va. 2007) (filed rate doctrine did not bar challenge by competing gas shippers to defendants' "parking and lending" agreement under which defendants mutually allocated space for inventorying natural gas, because this agreement was not covered by any filed tariff); E.\&J. Gallo Winery v. Encana Energy Servs., Inc., 2005 WL 2230530, 2005-2 Trade Cas. I[74,955 (E.D. Cal. Sept. 14, 2005) (whether filed rate doctrine barred plaintiffs' claims presented a fact question where it was not clear that the retail rates paid by the plaintiff were determined in accordance with filed wholesale rates; the retail rates, which themselves were not filed, could have been set without any reference to the wholesale rates; court assumed that if the retail rate was "pegged," or formulated from the wholesale rate, then filing of the wholesale rate precluded a challenge to the retail rate).

${ }^{24}$ See Georgia v. Pa. R.R. Co., 324 U.S. 439 (1945). 
overcharge based on the filed rate. ${ }^{25}$ In Brown the Ninth Circuit applied similar reasoning to permit an antitrust action against an alleged cartel of title insurers: ${ }^{26}$ "if those rates were the product of unlawful activity prior to their being filed and were not subjected to meaningful review by the state, then the fact that they were filed does not render them immune from challenge."

Keogh generally offers no protection to rates that are merely filed but later are disapproved by the regulatory agency itself. In Groton ${ }^{27}$ and Litton, ${ }^{28}$ the Second Circuit allowed antitrust challenges to "ultimately 'disapproved tariffs... when...the regulatory agency expressly refuses to commit itself pending investigation." However, the protection does run to rates that are filed and approved but are subsequently disapproved by a court. In Wheat Rail ${ }^{29}$ the Seventh Circuit concluded that all Keogh required was Commission approval. Once that approval was given, the rate became mandatory, and to make it the basis for a later antitrust claim would impose too much uncertainty on the carrier. ${ }^{30}$ Indeed, refusing to apply the doctrine to judicially disapproved rates would eviscerate it, for the entire premise of challenges to filed rates is that there is something wrong with them, and a court that awarded treble antitrust damages for filed rate overcharges would in effect be disapproving them.

Most courts hold that Keogh precludes only antitrust claims going to the amount of a filed rate for a purchased service. Thus the Litton court also held Keogh inapplicable to AT\&T's imposition of a charge for an "interconnection" device it required before connecting Litton to its system. Although Litton was a customer with respect to the charge and the charge was filed as a tariff, the issue was "not the reasonableness of the interface tariff rate as compared to some other rate that might have been charged, but instead whether the [interface] requirement itself was reasonable, i.e., whether there should have been any charge at all." ${ }^{31}$ However, in Stanislaus the Ninth Circuit barred one particular claim of refusal to deal. ${ }^{32}$ The plaintiffs alleged that because the defendant purchased large quantities of gas, it did not have pipeline space available for

${ }^{25}$ Congress responded to Georgia by passing the Reed-Bulwinkle Act, 49 U.S.C. $\$ 10706$, which exempted joint ratemaking that has been presented to and approved by the ICC, but not a secret cartel unknown to the ICC.

${ }^{26}$ Brown v. Ticor Title Ins. Co., 982 F.2d 386 (9th Cir. 1992), cert. dismissed, 511 U.S. 117 (1994) (alleging that title insurers first fixed the rates for title search services and then submitted them to the agency).

${ }^{27}$ City of Groton v. Conn. Light \& Power Co., 662 F.2d 921, 929 (2d Cir. 1981).

${ }^{28}$ Litton Sys., Inc. v. AT\&T Co., 700 F.2d 785, 820 (2d Cir. 1983), cert. denied, 464 U.S. 1073 (1984).

${ }^{29}$ Wheat Rail Freight Rate Antitrust Litig., 759 F.2d 1305 (7th Cir. 1985), cert. denied, 476 U.S. 1158 (1986).

${ }^{30}$ Id. at 1315 .

${ }^{31}$ Litton, supra, 700 F.2d at 820. Cf. Paladin Assocs., Inc. v. Mont. Power Co., 97 F. Supp. 2d 1013 (D. Mont. 2000), aff'd but criticizing, 328 F.3d 1145 (9th Cir. 2003) (Keogh did not bar claims that were not based on the rate elements of a filed tariff, but on interconnection and duty to deal elements).

${ }^{32}$ Cnty. of Stanislaus v. PG\&E Co., 114 F.3d 858 (9th Cir. 1997), cert. denied, 522 U.S. 1076 (1998). 
the plaintiffs to make alternative gas purchase arrangements. As a result of the large purchases, the plaintiffs were both required to pay higher prices and in some cases were prevented from buying natural gas elsewhere. But, as the court noted, both the rate that the defendant charged and the quantity that it purchased had received agency approval, which established the "import volume as conclusively reasonable and thereby foreclose[d] any challenge to importation volumes." ${ }^{33}$

Finally, Keogh applies to rates that are filed with a government agency but not to rates set by private associations or committees. Thus in Wileman the Ninth Circuit refused to apply Keogh in a state antitrust challenge to rates made by private committees of producers appointed by the Secretary of Agriculture. ${ }^{34}$

\section{The Filed Rate Doctrine Under Deregulation}

Keogh's application becomes more complex and even less rational under partial deregulation. Today, for example, some rates must be "filed" with the overseeing agency although the agency has little power to adjust the rates except in extraordinary circumstances. For example, the Motor Carrier Act of $1980^{35}$ created a "zone of rate freedom" within which the now dismantled ICC had little authority to interfere with privately set trucking rates except on the complaint of another carrier or shipper. ${ }^{36}$

In Wheat Rail, ${ }^{37}$ the Seventh Circuit applied Keogh even though the Railroad Revitalization and Regulatory Reform $\mathrm{Act}^{38}$ forbade the ICC from questioning the reasonableness of a filed rate unless it first determined that those filing it had market dominance or independently found that the rates were unjustifiably discriminatory. The court declared that creating the "ICC's jurisdiction to prevent unjust discrimination in rates was the 'paramount' purpose of Congress in enacting the Interstate Commerce Act." ${ }^{39}$ Since the Regulatory Reform Act had not diminished the ICC's power over unjust discrimination, Keogh was to be fully applied.

In its far-ranging Texas Commercial Energy decision, the Fifth Circuit held that Keogh barred an electricity reseller's claim that it paid too high a rate to a regulated

${ }^{33}$ Id. at 864, citing Nantahala Power \& Light Co. v. Thornburg, 476 U.S. 953, 962-963 (1986), which in turn had concluded that Keogh is not limited to rates "per se" but also applied to the regulatory agency's allocation decision.

${ }^{34}$ Wileman Bros. \& Elliott, Inc. v. Giannini, 909 F.2d 332 (9th Cir. 1990). The decision raises issues of determining who is the state and who is a private party-often considered by courts addressing the Parker immunity. See $\$ 224$ b. Cf. Long Beach v. Standard Oil Co., 872 F.2d 1401, 1409 (9th Cir.), amended, 886 F.2d 246 (9th Cir. 1989), cert. denied, 493 U.S. 1076 (1990) (Keogh does not bar price-fixing claim against oil companies who claimed their jointly made prices were based on federally enacted price ceilings).

${ }^{35} 94$ Stat. 803, codified at 49 U.S.C. $\$ 10706(\mathrm{~b})(3)(\mathrm{B})-(\mathrm{D})$.

${ }^{36}$ The procedure is described in Am. Trucking Ass'n, Inc. v. United States, 755 F.2d 1292 (7th Cir. 1985).

${ }^{37}$ Wheat Rail Freight Rate Antitrust Litig., 759 F.2d 1305 (7th Cir. 1985), cert. denied, 476 U.S. 1158 (1986).

${ }^{38}$ Pub. L. 94-210, 90 Stat. 31 (1976), codified at 49 U.S.C. $\$ 10,709$.

${ }^{39}$ Wheat Rail, supra, 759 F.2d at 1311, quoting Keogh, 260 U.S. at 163. 
utility as a result of the latter's market manipulation. ${ }^{40}$ The court rejected the argument that Keogh did not apply because the agency did not regulate in the traditional sense and the actual rates charged were set by the market. The court affiliated itself with decisions in the First and Ninth Circuits:

We agree with the approach taken by other circuits....In Norwood $^{41}$...the First Circuit concluded that the filed rate doctrine applied to market-based energy rates because FERC was "responsible for ensuring 'just and reasonable' rates and, to that end, wholesale power rates continue to be filed and subject to agency review." ${ }^{22}$ The Ninth Circuit echoed this view, noting that while FERC had waived many requirements that it had applied under a cost-based system, the filed rate doctrine continued to apply to market-based energy rates because the agency continued to "oversee wholesale electricity rates... by reviewing and approving a variety of documents filed by [market actors]." ${ }^{43}$ Similarly, under Bill 7, PUCT [the state agency] is required to ensure "safe, reliable, and reasonably priced electricity" and "that ancillary services necessary to facilitate the transmission of electric energy are available at reasonable prices with terms and conditions that are not unreasonably preferential, prejudicial, discriminatory, predatory, or anticompetitive." PUCT also requires electricity generators to file detailed information to assess market power and even a market power mitigation plan for those generators that control more than $20 \%$ of the electricity market in a specific region. ${ }^{44}$

Nor was the court moved by an antitrust saving clause contained in the federal regulatory legislation. ${ }^{45}$ First, the court held, the filed rate doctrine was an inherent part

${ }^{40}$ Tex. Commercial Energy v. TXU Energy, Inc., 413 F.3d 503 (5th Cir. 2005), cert. denied, 546 U.S. 1091 (2006).

${ }^{41}$ Referring to Town of Norwood v. New England Power Co., 202 F.3d 408 (1st Cir.), cert. denied, 531 U.S. 818 (2000).

${ }^{42}$ Citing and quoting Id. at 419.

${ }^{43}$ Citing and quoting Pub. Util. Dist. No. 1 of Snohomish Cnty. v. Dynegy Power Mktg., Inc., 384 F.3d 756, 760-761 (9th Cir. 2004), cert. denied, 545 U.S. 1149 (2005).

${ }^{44}$ Texas Commercial, supra, 413 F.3d at 509-510, citing Tex. Util. Code Ann. $\$ 335.004(\mathrm{e})$, 39.101(a)(1), and 39.155-156.

${ }^{45}$ Tex. Util. Code Ann. §39.158(b):

Nothing in this chapter shall be construed to confer immunity from state or federal antitrust laws. This chapter is intended to complement other state and federal antitrust provisions. Therefore, antitrust remedies may also be sought in state or federal court to remedy anticompetitive activities. 
of federal antitrust policy, which state law could not remove even for state-regulated rates. ${ }^{46}$

With that, the court concluded that Keogh applied even though the rate was apparently not "filed" at all. Rather, it was enough that the state regulatory commission exercised "oversight over the market." 47 This seems to be an unwarranted extension of a doctrine that even the Supreme Court concedes is justified only by precedent. As weak as Keogh's rationales for the filed rate doctrine were when they were first formulated, they are virtually nonexistent when the rate in question is not subject to filing at all and the firm has unrestrained power to set its own rates. Nothing in either of the Supreme Court's Keogh or Square $D$ decisions suggests that an agency's background regulation should serve as a substitute for a filed rate, particularly when there is no evidence that the state agency was actively regulating the market in question. The issues that the court was addressing should more properly have been considered under the "state action" doctrine ${ }^{49}$ a doctrine that would have required a clear declaration of state policy to displace the antitrust laws and then a showing of active supervision of the privately set prices.

In Berning ${ }^{50}$ the Ninth Circuit held that Keogh barred a challenge to alleged monopolistic prices of hops sold under marketing orders authorized by the Marketing Agreement Act of $1937^{51}$ and approved by the Secretary of Agriculture. The marketing orders did not stipulate the price at which the hops were to be sold; rather the orders allocated the amount of hop production for sale that would be permitted to hop producers. In applying Keogh, the court equated regulatory approval of an output level with approval of a price. While this outcome might be correct in a case involving hops, which we presume have no good substitutes, it might not be correct in a case such as railroad transportation, for which trucking or other transport modes are substitutes. In such a case an order limiting the volume of railroad transportation would not necessarily increase its price, for the decline in railroad transportation might be offset by an increase in competing truck or other forms of transportation. In sum, the Ninth Circuit's conclusion was valid only on the premise that hops define a relevant market.

Even then, one wonders whether the logic of Keogh applies. For example, goods

${ }^{46}$ Texas Commercial, supra, 413 F.3d at 508-509. Somewhat problematically, the court also held that the Saving Clause immunized the rate from challenge under state antitrust law. The court noted that the federal Keogh rule applies to both federal and state filed rates, citing H.J. Inc. v. Nw. Bell Tel. Co., 954 F.2d 485, 494 (8th Cir. 1992); Taffet v. S. Co., 967 F.2d 1483 (11th Cir. 1992); Korte v. Allstate Ins. Co., 48 F. Supp. 2d 647 (E.D. Tex. 1999). In addition it held that the state claims "do not need to be addressed separately" because the state statute "mandates that its provisions be interpreted in harmony with federal antitrust law," citing Johnson v. Hosp. Corp. of Am., 95 F.3d 383, 391 n.7 (5th Cir. 1996). However, a general rule of construction would usually give way to a specific provision such as this saving clause.

${ }^{47}$ Texas Commercial, supra, 413 F.3d at 509-510.

${ }^{49}$ See 1A ANTITRUST LAW III224-227.

${ }^{50}$ See Berning v. Gooding, 643 F. Supp. 26, 29 (D. Or. 1985), aff'd, 820 F.2d 1550 (9th Cir. 1987).

${ }^{51} 7$ U.S.C. $\$ \S 601$ et seq. 
sold subject to an agency-approved output limitation but not price controls could be sold to different buyers at different prices, especially in markets where price discrimination is possible, thus undermining Keogh's concerns about price discrimination. Further, the best policy is generally to construe irrational doctrines narrowly and, as the Supreme Court virtually conceded in Square $D$, the filed rate doctrine in antitrust is in large measure irrational and justifiable only on grounds of stare decisis. ${ }^{52}$

As previously noted, Keogh's limitation to "filed" rates is particularly relevant in a deregulated regime. For example, federal legislation passed in 1995 abolishes many of the attributes of motor transport regulation, including for many carriers any requirement that rates be filed with an agency. Rather, certain classes of rates must be published privately by the carrier and made available to prospective customers. ${ }^{53}$ Because such rates are not submitted to any regulatory agency and thus are not subjected to agency review even in principle, they enjoy no Keogh immunity.

\section{Competitor Suits}

Justice Brandeis's rationales for the filed rate doctrine given in Keogh apply mainly, if not exclusively, to challenges brought by customers claiming that the rate is monopolistic or the product of collusion. Square $D$ was also a suit by firms who acted only as purchasers. ${ }^{54}$ Competitor lawsuits are a different matter. Many courts have allowed antitrust damage actions by actual or potential competitors against allegedly predatory filed rates. For example, in Cost Management and Barnes the Ninth Circuit permitted challenges to allegedly predatory rates designed to exclude potential competitors from the market. ${ }^{55}$ Similarly, Kirkwood allowed a claim that defendant's filed rates imposed a "price squeeze" upon the plaintiff. ${ }^{56}$

Of course, in competitor lawsuits damages are ordinarily based on the plaintiff's lost

${ }^{52}$ For thoughtful commentary, see Jim Rossi, Lowering the Filed Tariff Shield: Judicial Enforcement for a Deregulatory Era, 56 Vand. L. Rev. 1591 (2003).

${ }^{53}$ See also CTC Commc'ns v. Bell Atl. Corp., 77 F. Supp. 2d 124 (D. Me. 1999) (no filed rate immunity for BOC's unreasonable terms in selling wholesale communications services for resale, when the policies were not contained in any filed tariffs). Cf. Tex. Commercial, supra, 413 F.3d 503.(apparently applying Keogh to a rate that was not filed in the traditional sense).

${ }^{54}$ Actually, it was a class action by a group of shippers against an alleged cartel of trucking companies. See Square D Co. v. Niagara Frontier Tariff Bureau, Inc., 760 F.2d 1347 (2d Cir. 1985), aff'd, 476 U.S. 409, 411 (1986).

${ }^{55}$ Cost Mgmt. Serv., Inc. v. Wash. Natural Gas Co., 99 F.3d 937, 944-945 (9th Cir. 1996) (citing ANTITRUST LAw, and Herbert Hovenkamp, Federal Antitrust Policy: The Law of Competition and Its Practice $\$ 19.6$ (4th ed. 2011); Barnes v. Arden Mayfair, Inc., 759 F.2d 676 (9th Cir. 1985).

${ }^{56}$ City of Kirkwood v. Union Electric Co., 671 F.2d 1173, 1178 (8th Cir. 1982), cert. denied, 459 U.S. 1170 (1983). On price squeezes generally, see 3B ANTITRUST LAW II767c; in the public utility context, see id., $₫ 787 \mathrm{c} 2$.

Cf. Arroyo-Melecio v. Puerto Rican Am. Ins. Co., 398 F.3d 56, 73-74 (1st Cir. 2005) (filed rate doctrine did not bar claim by consumers that insurers conspired to boycott a broker who was attempting to bring into the market more competitive nonconspiring insurers). 
profits rather than on a claim that it paid too much. ${ }^{57}$ Thus at least some of the rationales given for Keogh would seem not to apply. Nevertheless the courts are not entirely in agreement. Even where railroads were charged with illegally combining to fix prices and to monopolize the movement of iron ore through Lake Erie docks to inland steel mills, the Sixth Circuit held in Pinney Dock that a rival dock owner was precluded by Keogh from obtaining damages based on allegedly excessive railroad rates that the plaintiff or its customers paid. ${ }^{59}$ The court declined to regard Keogh either as irrelevant to a competitor's suit or as a total bar.

By contrast, the Third Circuit, looking at part of the same alleged conspiracy, found Keogh inapt. ${ }^{60}$ Although "the success of anticompetitive non-rate activity would coincidentally implicate rates promulgated under the jurisdiction of the ICC," it was "fully consistent" with Keogh "to accept these rates as lawful and nonetheless to conclude that through non-rate activities...the railroads effectively retarded entry of lower cost competitors into the market." The court concluded that the filed tariff doctrine has "little or nothing to do" with the regulated firms' duties to its competitors, who are not "the intended beneficiaries" of this rule of public utility regulation. ${ }^{6}$

We agree with those decisions refusing to apply Keogh to competitor suits. First, as Ia noted, Keogh is difficult to justify on policy grounds. The more recent Square $D$ decision, which was also a consumer suit, rested entirely on stare decisis, and stare decisis is no reason for expanding the domain of a poor decision. Second, anticompetitively low rates by regulated firms can be a much more significant problem than predatory pricing generally, which is quite rare. ${ }^{62}$ In many regulatory regimes complex tariff structures permitting different prices to different market segments are common, and a frequent result is cross-subsidization; that is, high rates from one part of the regulated market are used to offset low rates in another part. Absent effective agency supervision, such a scheme can be used to exclude rivals from one portion of the market. For example, AT\&T once allegedly used high local telephone rates to offset artificially low long distance rates, thus making it more difficult for other firms to provide long distance service in competition with AT\&T. The low rates for local service did not attract new entry, however, because AT\&T had both a hard-wired natural monopoly as

${ }^{57}$ Del. \& Hudson Ry. Co. v. Consol. Rail Corp., 654 F. Supp. 1195, 1205 (N.D.N.Y. 1987) ("The plaintiff's damages will be measured not by the difference between existing rates and some hypothetical rates, but by business losses it has allegedly sustained").

${ }^{59}$ Pinney Dock \& Transport Co. v. Penn Cent. Corp., 838 F.2d 1445 (6th Cir.), cert. denied, 488 U.S. 880 (1988).

${ }^{60}$ Lower Lake Erie Iron Ore Antitrust Litig., 998 F.2d 1144 (3d Cir.), cert. dismissed, 510 U.S. 1021, 1032 (1993). See also Capital Freight Servs., Inc. v. Trailer Marine Transport Corp., 704 F. Supp. 1190 (S.D.N.Y. 1989), which stated the issue in similar terms, disagreed with Pinney, and declared that Square D "saved Keogh from extinction" but "did not breathe a new expansive energy into the doctrine." Id. at 1195. It regarded Pinney as expanding Keogh, although it recognized that Pinney merely excluded recovery based on allegedly excessive rates charged a customer who was also a competitor. Id. at $1195 \&$ n.2.

${ }^{61}$ Lower Lake Erie, supra, 998 F.2d at 1161, quoting Essential Commc'ns Sys., Inc. v. AT\&T Co., 610 F.2d 1114, 1121 (3d Cir. 1979).

${ }^{62}$ See 3 A ANTITRUST LAW Ch. 7C. 
well as a statutory monopoly of local service ${ }^{63}$ Finally, the regulatory process is typically quite solicitous of the views of customers but frequently much less so of the views of competitors who might be affected by discriminatory rates.

In such cases Keogh should not be applied as an additional bar to antitrust enforcement. Rather, application of the antitrust laws should rest, as it usually does, on the power of the agency to immunize conduct and the extent and nature of its supervision. The problem with Keogh, as previously noted, is that its immunity is invoked merely upon the "filing" of the rate in question, with no attention given to the degree of government supervision or review of the ratemaking process.

Finally, as the previous discussion suggests, some firms stand in both a purchaser and a competitor relationship to the regulated firm. This is common in the telecommunications industry, where competitive local exchange carriers, or CLECs, typically purchase telecommunications services from incumbent local exchange carriers, or ILECs. In such cases the CLEC's status under Keogh depends on the nature of the antitrust challenge. For example, if the claim is that the CLEC is overcharging for some service, Keogh should bar the claim. ${ }^{64}$ By contrast, if the claim is one of exclusionary practices targeting the plaintiff as a rival, Keogh would not apply. ${ }^{65}$

In Utilimax the plaintiff purchased power from the defendant, a power generator, and then resold it in competition with the defendant. ${ }^{66}$ The Third Circuit refused to apply a "competitor" exception to Keogh. Although the plaintiff competed with the defendant in resale, the basis of the suit was the high prices it was forced to pay to the defendant, thus making it a customer rather than a competitor for the purposes of this lawsuit. ${ }^{67}$ By contrast, Frontier permitted a filed tariff to be challenged by a plaintiff who both bought from and competed with the defendant. ${ }^{68}$ The tariff was allegedly designed to prevent the plaintiff from entering a particular part of the tour bus market.

\section{Equity Relief vs. Damages}

In its Georgia ${ }^{69}$ decision the Supreme Court indicated that the Keogh holding applied

${ }^{63}$ See 3B ANTITRUST LAW $1[786$.

${ }^{64}$ The courts have so held with respect to consumer claims against CLECs. See Goldwasser v. Ameritech Corp., 222 F.3d 390, 402 (7th Cir. 2000); and Stein v. Pac. Bell Tel. Co., 173 F. Supp. 2d 975 (N.D. Cal. Feb. 14, 2001), aff'd in part, vacated in part, 172 Fed.Appx. 192 (9th Cir. 2006), on remand, 2007 WL 831750 (N.D.Cal. 2007).

${ }^{65}$ See Tex. Commercial Energy v. TXU Energy, Inc., 413 F.3d 503, 509-510 (5th Cir. 2005), cert. denied, 546 U.S. 1091 (2006). (although defendant electric utility was both generator and distributor, Keogh applied when the claims were based on its role as supplier to the plaintiff distributor).

${ }^{66}$ Utilimax.com, Inc. v. PPL Energy Plus, LLC, 378 F.3d 303 (3d Cir. 2004).

${ }^{67}$ Accord Pinney Dock \& Transport Co. v. Penn Cent. Corp., 838 F.2d 1445 (6th Cir.), cert. denied, 488 U.S. 880 (1988), explained by Capital Freight Servs., Inc. v. Trailer Marine Transport Corp., 704 F. Supp. 1190, 1195 \& n.2 (S.D.N.Y. 1989).

${ }^{68}$ Frontier Enters., Inc. v. Amador Stage Lines, Inc., 624 F. Supp. 137 (E.D. Cal. 1985). See also Del. \& Hudson Ry. Co. v. Consol. Rail Corp., 654 F. Supp. 1195, 1205 (N.D.N.Y. 1987).

${ }^{69}$ Georgia v. Pennsylvania R.R. Co., 324 U.S. 439, 454-462 (1945). 
to damages claims but not to equity claims - that is, that the doctrine operated not as an "immunity" but rather as a limitation on damages awards. As the Court then elaborated in Square $D$ :

We disagree, however, with petitioners' view that the issue in Keogh and in this case is properly characterized as an "immunity" question. The alleged collective activities of the defendants in both cases were subject to scrutiny under the antitrust laws by the Government and to possible criminal sanctions or equitable relief. Keogh simply held that an award of treble damages is not an available remedy for a private shipper claiming that the rate submitted to, and approved by, the ICC was the product of an antitrust violation. Such a holding is far different from the creation of an antitrust immunity, and makes the challenge to Keogh's role in the settled law of this area still more doubtful. ${ }^{70}$

In its Norwood decision, ${ }^{71}$ however, the First Circuit distinguished both, noting that both cases alleged a cartel that filed a rate, and an injunction would do no more than prohibit the firms from colluding in the future prior to their rate filings. In contrast, the case in front of it involved unilateral conduct, and an injunction would require the defendant to alter its tariffs, something that Keogh prohibited. ${ }^{72}$

${ }^{70}$ Square D Co. v. Niagara Frontier Tariff Bureau, Inc., 760 F.2d 1347 (2d Cir. 1985), aff'd, 476 U.S. 409, 422 (1986). The Court observed in a footnote that “... a critical distinction remains between an absolute immunity from all antitrust scrutiny and a far more limited nonavailability of the private treble-damages remedy...." Id., n.28.

See also McLain v. Real Estate Bd. of New Orleans, Inc., 444 U.S. 232, 243 (1980), citing Keogh for this proposition:

Even where there is an inability to prove that concerted activity has resulted in legally cognizable damages, jurisdiction need not be impaired, though such a failure may confine the available remedies to injunctive relief. See Georgia v. Pennsylvania R. Co., 324 U.S. 439, 452-463 (1945); Keogh v. Chicago \& N.W. R. Co., 260 U.S. 156 (1922).

Accord Hawaii v. Standard Oil Co. of Cal., 405 U.S. 251, 260 (1972); Goldwasser v. Ameritech Corp., 222 F.3d 390, 395 (7th Cir. 2000).

${ }^{71}$ Town of Norwood v. New England Power Co., 202 F.3d 408, 419 (1st Cir.), cert. denied, 531 U.S. 818 (2000).

${ }^{72}$ See id. at 419-420:

Norwood also objects that the filed rate doctrine only protects against damage claims and, it says, in this instance it seeks declaratory and injunctive relief; apparently it contemplates relief that would block or 
Two situations must be distinguished, however. Keogh very likely does preclude an injunction that would require a firm to charge in the future a rate different from a previously filed tariff mandated. ${ }^{73}$ But there is no reason to think Keogh would prohibit an injunction against an antitrust violation attending some tariff that would or might be filed in the future. Such a tariff has not been "filed" at all.

\section{Rates Filed With State Regulators}

Supreme Court analysis of filed rates has focused on rates filed with federal regulatory agencies. By contrast, several lower court decisions have extended the doctrine to rates filed with state regulators, generally without distinguishing the issues. ${ }^{1}$

nullify the termination charge and possibly require the wholesale standard offer rates to be made available to it....

But in Georgia and Square D, the Court was concerned with possible price-fixing conspiracies that conceivably could have been enjoined without tampering with the tariffed rates themselves, the relief would merely assure non-collaborative individual filings by the supposed conspirators. Here, any meaningful relief as to the price squeeze would require the alteration of tariffs - and not merely tariffs subject to regulation but tariffs actually scrutinized repeatedly by FERC in the companion-case proceedings. In part, the rationale for the filed rate doctrine is to protect the exclusive authority of the agency to accept or challenge such tariffs, - a goal that would be undermined by Norwood's distinction in the present case.

${ }^{73}$ See Arsberry v. Illinois, 244 F.3d 558, 563 (7th Cir.), cert. denied, 534 U.S. 1062 (2001):

If the plaintiffs in this case wanted to get a rate change, the version of the doctrine that we have described would kick in; but they do not, so it does not. Eventually they want a different rate, of course, but at present all they are seeking is to clear the decks - to dissolve an arrangement that is preventing the telephone company defendants from competing....

Accord Tex. Commercial Energy v. TXU Energy, Inc., 413 F.3d 503, 508 (5th Cir. 2005), cert. denied, 546 U.S. 1091 (2006).

${ }^{1}$ See, e.g., Sun City Taxpayers' Ass'n. v. Citizens Utilities Co., 45 F.3d 58 (2d Cir. 1995) (RICO challenge against rate filed with state corporation commission barred by filed rate doctrine); Texas Commercial Energy v. TXU Energy, Inc., 2004 WL 1777597, 2004-2 Trade Cas. \$774,497 (S.D. Tex. June 24, 2004), aff'd, 413 F.3d 503 (5th Cir. 2005), cert. denied, 546 U.S. 1091 (2006) (doctrine applied to bar rates filed with a state utility commission in a situation outside of FERC's jurisdiction; see district court's discussion of intent of Texas legislature); Green v. Peoples Energy Corp., 2003 WL 1712566, 2003-1 Trade Cas. I[73,999 (N.D. Ill. Mar. 28, 2003) (filed rate doctrine precluded tying challenge to tariff requirement file with state regulator of retail electricity that made company-installed gas meters mandatory and required customers to pay a fee for them). See also Goldwasser v. Ameritech Corp.,No. 97 C 6788, 1998 WL 60878, at 
The issue must be distinguished from situations in which plaintiffs attempt to apply state law to rates filed with federal agencies - in that case the filed rate doctrine clearly applies. $^{2}$

Extending the doctrine to state agencies raises the troublesome issue that rate filings may serve to confer an effective antitrust immunity in situations where antitrust's "state action" doctrine would not apply. Interestingly, the Supreme Court's Cantor decision permitted an antitrust challenge to a tariff filed with a state regulator by finding that the "state action" doctrine did not apply, but never discussed the filed rate doctrine. ${ }^{3}$

The filed rate doctrine does not contain anything equivalent to the "active supervision" requirement that the state action doctrine compels. ${ }^{4}$ Indeed, it does not even contain an equivalent to the authorization requirement. ${ }^{5}$ For example, a state provision may authorize an exclusionary tariff, giving no thought to competitive consequences. The state agency in turn may approve such requests with little or no evaluation. While the provision in question is unlikely to survive scrutiny under the state action doctrine, the tariff filing itself may have effective immunity under the filed rate doctrine. The Third Circuit's McCray decision applied the filed rate doctrine to price fixing among title insurers, expressly rejecting the argument that application required the defendant's to show "meaningful review" by the state regulator. ${ }^{6}$ The court found "no apparent requirement" that the "state action" and filed rate doctrine be "reconciled." The court did hold that the requirements for state action immunity would probably have been met in any event.

Congress has the authority to create an antitrust immunity even over unsupervised private conduct, if it wishes to do so. The fact that the filed rate doctrine requires no real supervision has led us to propose that the doctrine be construed

*7 (N.D.Ill. Feb. 4, 1998), aff'd, 222 F.3d 390, 402 (7th Cir.2000) (applying doctrine to rates approved by state public utility comhmissions); H.J. Inc. v. Northwestern Bell Tel. Co., 954 F.2d 485, 494 (8th Cir.1992) ("the rationale underlying the filed rate doctrine applies whether the rate in question is approved by a federal or state agency"); Taffet v. Southern Co., 967 F.2d 1483, 1494 (11th Cir.1992) (doctrine "applies with equal force" to state and federal agency rates). Contrast Brown v. Ticor Title Ins. Co., 982 F.2d 386 (9th Cir. 1992) (refusing to apply filed rate doctrine to title insurance tariffs filed with state regulators).

${ }^{2}$ E.g., AT\&T Co. v. Central Office Tel. Co., 524 U.S. 214 (1988) (filed rate doctrine barred state law contract and tort claims challenging federally filed rate).

${ }^{3}$ Cantor v. Detroit Edison Co., 428 U.S. 579 (1976). Nor did the district court discuss the doctrine; the Sixth Circuit affirmed per curiam. See 392 F.Supp. 1110 (E.D. Mi. 1974), aff'd per curiam, 513 F.2d 630 (6th Cir. 1975).

${ }^{4}$ See 1 ANTITRUST LAW IIII226-227.

${ }^{5}$ See id., III224-225.

${ }^{6}$ McCray v. Fidelity Nat. Title Ins. Co., 682 F.3d 229 (3d Cir. 2012).

${ }^{7}$ Id. at 238 n.6. See also New Jersey Title Ins. Litig., 683 F.3d 451 (3d Cir. 2012). Cf. Sun City Taxpayers' Ass'n. v. Citizens Utilities Co., 45 F.3d 58 (2d Cir. 1995) (RICO challenge against rate filed with state corporation commission barred by filed rate doctrine). 
narrowly. But the states do not have the authority to create a federal antitrust immunity over unauthorized or unsupervised private conduct at all. The most sensible approach would be to limit application of the filed rate doctrine as applied to state regulators only when the regulatory regime in question would qualify for state action immunity. Indeed, that seems inherent in Supreme Court decisions such as Midcal and Cantor, where the provisions found not to be immune under the federal antitrust laws were in fact contained in rates or tariffs filed with a state regulator. ${ }^{8}$ It is perhaps relevant that questions concerning the scope of the filed rate doctrine to state antitrust law challenges to rates filed with state agencies raise only questions of state law. ${ }^{9}$

${ }^{8}$ California Retail Liquor Dealers Ass'n v. Midcal Alum., Inc., 445 U.S. 97, 99 \& n. 1 (1980) (noting that challenged wine prices had to be filed with state agency); Cantor v. Detroit Edison Co., 428 U.S. 579, 598 (1976). Cf. FTC v. Ticor Title Ins. Co., 504 U.S. 621, 629 (1992) (rates filed with insurance regulator; case brought by government agency).

\footnotetext{
${ }^{9}$ E.g., Knevelbaard Dairies v. Kraft Foods, Inc., 232 F.3d 979 ( ${ }^{\text {th }}$ Cir. 2000).
} 